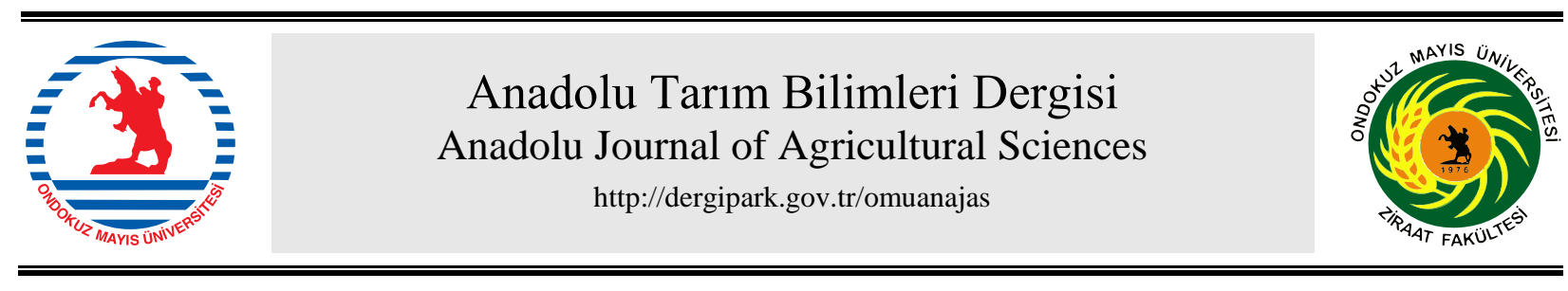

Araştırma/Research

\section{TR83 Bölgesinde buğday tohumluğu üretiminde teknik etkinlik ve etkinliği belirleyen faktörler ${ }^{1}$}

\author{
Kerem Hazneci*, Vedat Ceyhan \\ Ondokuz Mayıs Üniversitesi, Ziraat Fakültesi, Tarım Ekonomisi Bölümü, Samsun/Türkiye \\ *Sorumlu yazar/corresponding author: kerem.hazneci@omu.edu.tr
}

Geliş/Received 11/08/2016 Kabul/Accepted 13/02/2017

\section{ÖZET}

Bu araştırmanın temel amacı, Türkiye'de TR83 bölgesinde buğday tohumluğu yetiştiriciliğinde teknik etkinliği ölçmek ve teknik etkinliği belirleyen faktörleri ortaya koymaktır. Araştırma verileri buğday tohumluğu yetiştiren işletmelerin tamamı olan 72 tarım işletmesinden anket yoluyla toplanmıştır. İncelenen işletmelerin ekonomik analizinde klasik ekonomik analiz yaklaşımları kullanılmıştır. İşletme düzeyinde teknik etkinliğin ölçülmesinde ve etkinliği belirleyen faktörlerin ortaya konulmasında stokastik sınır modelinden yararlanılmıştır. Etkinlik analizi sonuçları inceleme alanında teknik etkinliğin 0.68 ile 0.96 arasında değiştiğini ve ortalama 0.81 olduğunu göstermiştir. İncelenen işletmeler teknik yetersizliklerini ortadan kaldırarak, üretim miktarında hiçbir azalma olmaksızın kullandıkları girdi miktarlarını \% 19 oranında azaltabileceklerdir. Buğday tohumluğu yetiştiriciliğinde tohum, gübre ve işgücü dışında kalan diğer değişken masrafların gereğinden fazla olduğu ve bunun teknik etkinliği düşürdüğü saptanmıştır. Eğitim, kayıt tutma durumu, aile büyüklüğü ve tohumluk üretimine tahsis edilen alan değişkenlerinin buğday tohumluğu üretim etkinliğini belirleyen önemli değişkenler olduğu tespit edilmiştir. İncelenen işletmelerde kullanılan tohum miktarını ve diğer değişken masrafların hemen hemen tamamını tohumluk yetiştiren işletmeyle sözleşme yapan tohum üretici firmalar belirlediğinden, tohum yetiştiren firmaların tohumluk yetiştiriciliğiyle ilgili teknik uygulamaları gözden geçirmesi ve daha doğru olan uygulamaların işletmeler tarafindan uygulanmasını sağlamaları buğday tohumluğu yetiştiriciliğinde teknik etkinliği artırabilecektir.

Assesing the technical efficiency of farms producing wheat seed and its determinants in TR83 region, Turkey

\section{ABSTRACT}

The main objectives of this study were to evaluate the technical efficiency in wheat seed growing and to determine the factors affecting technical efficiency in TR83 region of Turkey. Data were collected from 72 wheat seed-growing farms by using questionnaire. Conventional economic analysis approaches were used for the economic analysis of the farms surveyed. Stochastic Frontier Analysis (SFA) was used to assess the technical efficiency at farm level and to estimate the parameters affecting technical efficiency. The results of efficiency analysis revealed that technical efficiency in the study area ranged from 0.68 to 0.96 (mean 0.81). By eliminating the technical inefficiency, the sample farms will be able to reduce their amount of input use with a rate of $19 \%$ without any reduction in the amount of production. It was determined that other variable costs except for seed, fertilizer and labor in wheat seed growing were redundant, and this resulted in decreasing the technical efficiency. Study results also revealed that variables such as education status, record keeping, family size and the land allocated to wheat seed production were the important variables influencing wheat seed growing activities. Since seed growing companies, who contracted with seed growers, determine the amount of all inputs such as seed, fertilizer, etc. used for wheat seed production, revising their technical applications for seed growing and auditing the farms for more accurate implementations to be used by them in practice may increase the technical efficiency level of sample farms in wheat seed production.
Anahtar Sözcükler: Buğday tohumluğu TR83 Bölgesi Stokastik sinır modeli Teknik etkinlik

Keywords:

Wheat seed

TR83 region

Stochastic Frontier

Analysis

Technical efficiency

C) OMU ANAJAS 2017

\footnotetext{
${ }^{1}$ Bu çalışmanın bir kısmı ICAFOF 2017/ Nevşehir adlı kongrede sözlü bildiri olarak sunulmuştur.
} 


\section{Giriş}

Günümüzde sahip olunan sınırlı doğal kaynaklarla hızla artan nüfusun gıda ihtiyacını karşılamak giderek güçleşmektedir. $\mathrm{Bu}$ sebeple, bütün ulusların tarım sektörüne tahsis ettikleri kaynakları verimli ve etkin kullanması gerekmektedir. Kaynakların verimli ve etkin kullanımı, hali hazırda tarım sektörünün mutlak ve nispi olarak büyük pay aldığından gelişmekte olan ülkeler için daha büyük önem taşımaktadır. Türkiye'de 2014 yılında tarım sektörü; gayri safi yurt içi hâsılaya (GSYİH) sağladığı katkı (\% 7.1), istihdam katkısı (toplam istihdamın \% 22'si), ihracat yoluyla sağladığı döviz katkısı (6 milyar \$) ve sanayi mallarına oluşturduğu talep ile halen önemini korumaktadır (URL-1).

Dolayısıyla kaynakların verimli ve etkin kullanımı Türkiye'de politika yapıcıların gündeminde olan önemli bir konudur. Tarım işletmelerinin üretimde etkinliği sağlayabilmesi için hem üretim sürecinde kullandıkları üretim faktörlerini teknik olarak iyi değerlendirmeleri, hem de tarım ürünleri ve girdi piyasalarında meydana gelen değişikliklere uyum sağlayacak esnek bir yapıya kavuşmaları gerekmektedir. Bu sebeple karar alıcılar ve uygulayıc1 kuruluşlar, tarım ürünleri üretimini gerçekleştiren tarım işletmelerinin sahip oldukları kaynakları verimli ve etkin kullanmasını sağlamak için büyük çaba sarf etmektedirler.

Tarımda girdi kullanımı, gerek bitkisel ve gerekse hayvansal üretimde verimin dolayısıyla üretim miktarının artmasında, kalitenin yükseltilebilmesinde en temel unsurdur. Bitkisel üretim faaliyetinde kullanılan temel üretim girdilerinin en önemlilerinden biri olan tohumluk, tarım ürünleri üretiminde verim ve üretimi artırmasının yanı sıra daha dayanıklı, daha az maliyetli ve rekabet gücü yüksek kaliteli ürünlerin elde edilmesi bakımından da büyük önem taşımaktadır.

$\mathrm{Bu}$ öneminden dolayı Türkiye'de ve dünyada tohum sektörünün genel değerlendirilmesini yapmak, tohum üretimini ve ticaretini irdelemek, tohum yetiştiriciliğini analiz etmek ve sözleşmeli yetiştiricilik modeli ile tohum üretimi ilişkisini ortaya koymak amaçlarıyla günümüze kadar farklı yerlerde araştırmalar yapılmıştır. $\mathrm{Bu}$ araştırmaların hemen hemen tamamı ikincil verilere dayanmakta olup, işletme düzeyinde verilere dayanarak gerçekleştirilen araştırma sayısı oldukça sınırlıdır. Günümüze kadar tohum kullanımına, tohum üretim durumuna, tohum pazarlama yapısına, tohum dağıtımı ve ticaretine yönelik araştırmalar (Balcı, 1993; Usal, 1996; Akdoğan, 2005; Arısoy, 2005; Demirtaş ve Keleş, 2005; Acar, 2008; Yağdı ve diğ., 2010) yapılmıș olmasina rağmen, tohumluk yetiştiren işletmelerin teknik etkinliğini ele alan araştırma sayısı sınırlıdır (Ike, 2008; Khanal ve diğ., 2012; Srinivas ve diğ., 2012). Bu sebeple araştırmada, Türkiye'de TR83 bölgesinde yer alan üç ilde (Tokat, Amasya, Çorum) buğday tohumluğu yetiştiriciliğinde teknik etkinliğgi ölçmek, teknik etkinliği belirleyen faktörleri belirlemek amaçlanmıştır. Araştırma sonucunda elde edilen çıktılar işletme düzeyinde teknik etkinlik skorları ve teknik etkinliği belirleyen faktörlerden oluşmaktadır. Araştırmadan elde edilen çıktıların tohumluk yetiştiren işletmeler, tohum üretimi yapan işletmeler, politika yapıcılar ve bu konuda daha sonra çalışacak araştırıcılar üzerine yaygın etkisi olması beklenmektedir.

\section{Materyal ve Yöntem}

\section{Materyal ve Yöntem}

\subsection{Araştırma bölgesi}

Amasya, Çorum, Samsun ve Tokat illerini kapsayan TR83 Bölgesi $37294 \mathrm{~km}^{2}$ ile Türkiye yüzölçümünün yaklaşık olarak \% 5'ini kapsamakta ve yaklaşık 2.75 milyon kişi olan 2016 yılı nüfusu ile Türkiye nüfusunun \% 3.4'ünü oluşturmaktadır (Şekil 1), (URL-1). TR83 Bölgesi tarımsal alan ve üretim bakımından oldukça zengindir. Birçok bitkinin ve hayvan ırkının yetiştirilmesine uygun koşullar bulunmaktadır. Bölgesel gayrisafi katma değer incelendiğinde, tarım sektörünün bölge ekonomisi içindeki payının 2014 yılında \% 18.5 olduğu görülmektedir. $\mathrm{Bu}$ oran sektörün Türkiye ekonomisi içindeki payının iki katından fazladır (URL2).

TR83 Bölgesi'ni Türkiye genelinden ayıran bir özellik te tarım sektörünün, istihdam açısından önemini korumasidır. Yıllar boyunca tarımdan, ticaret ve hizmet sektörüne bir kayma yaşanmışsa da 2014 yılı itibarıyla tarım sektörü toplam istihdamdaki \% 42.2'lik oranı ile temel sektör olma özelliğini korumaktadır (URL-2). Bölge, bitkisel üretim miktarı ve verimlilik açısından Türkiye'de ilk sıralarda yer almaktadır. Bölge bitkisel üretimi 2016 'da 10.28 milyon ton olarak gerçekleşmiş ve ülke toplam üretiminin \% 7.23'ünü karşılamıştır. (URL-3).

\subsection{Materyal}

Araştırma materyalini TR83 Bölgesinde buğday tohumluğu yetiştiren işletmelerden 2013 yılı KasımAralık ve 2014 yılı Ocak-Şubat aylarında anket yoluyla toplanan veriler oluşturmuş̧ur. Araştırmada 2012-2013 üretim dönemi esas alınmıştır. Tamsayım metodu kullanılan araştırmada ana kitleyi, TR83 Bölgesinde yer alan ve 2012 yılında, 2013 üretim dönemi için tohumluk yetiştirme başvuru beyannamesi veren, Tokat, Amasya ve Çorum illerinde tohumluk yetiştiriciliği yapan 72 tarım işletmesi oluşturmuştur.

\subsection{Yöntem}

\subsection{1. İşletmelerin etkinlik analizinde uygulanan yöntem}

İnceleme alanında işletme düzeyinde teknik etkinliğin ölçülmesinde iki aşamalı yöntem (two-stage 
procedure) kullanılmıştır. Birinci aşamada teknik etkinlik skorları stokastik sınır modeli (SSM) yardımıyla tahmin edilmiş, ikinci aşamada ise teknik yetersizliği belirleyen faktörler analize dahil edilmiştir (Coelli ve ark., 1998). Araştırmada, teknik yetersizlik, incelenen işletmelerde yetiştirilen gerçek tohumluk miktarıyla $\left(\mathrm{kg} \mathrm{da}^{-1}\right)$, işletmelerdeki mevcut teknoloji düzeyinde sınır modeli ile tahmin edilen tohumluk miktarı $\left(\mathrm{kg} \mathrm{da}^{-1}\right)$ arasındaki uzaklık olarak tanımlanmıştır.

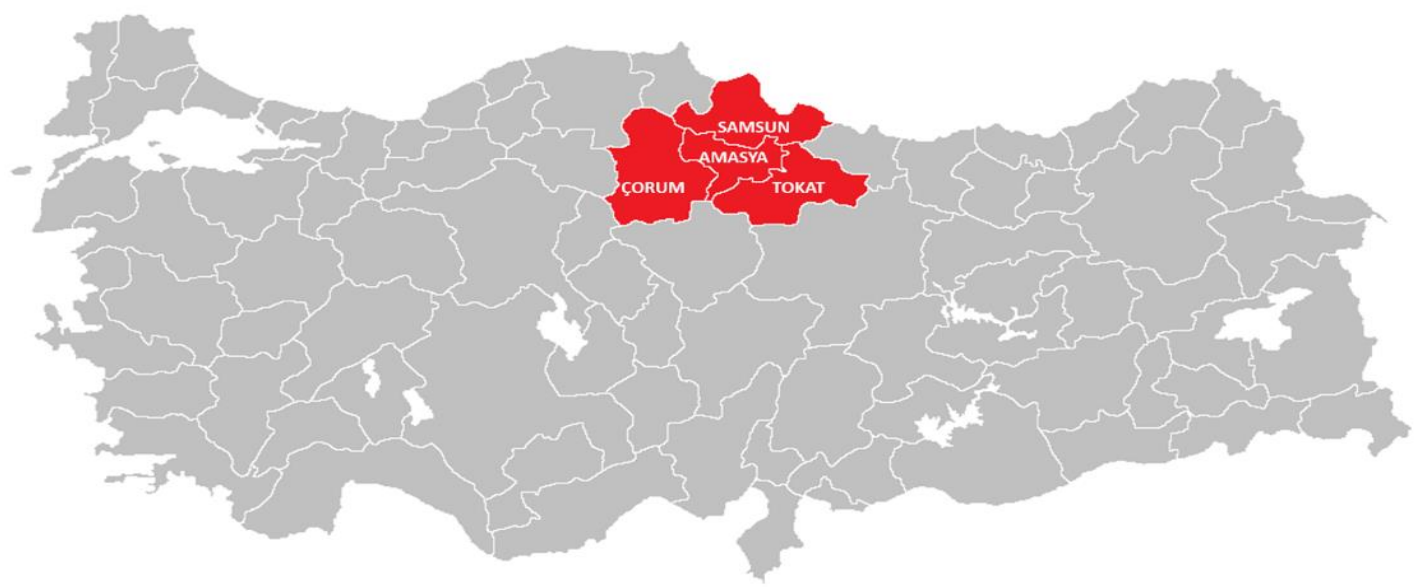

Şekil 1. Araştırma alanı (TR83 Bölgesi)

Buğday tohumluğu yetiştiriciliği yapan tarım işletmeleri için oluşturulan etkinlik modelinin genel çerçevesi aşağıdaki Eşitlik 1'deki gibidir (Battese ve Coelli, 1995; Coelli ve diğ., 1998):

$$
\ln \left(T_{i}\right)=\ln \left(X_{i}\right) \beta+V_{i}-U_{i}, \quad i=1, \ldots \ldots \ldots . ., n
$$

(Eşitlik 1)

Formülde; Ti; i'nci işletmenin tohumluk üretim miktarını, Xi; i'nci işletmenin girdilerini, $\beta$; girdiler ile çıktı arasındaki ilişkiyi gösteren parametreleri, Ui; negatif olmayan hata değişkenini ifade etmektedir ve bu değişken 0 ile 1 arasında değişmekte olup teknik etkinliği göstermektedir. Formülde yer alan Vi; ölçüm hatası, iklim koşulları gibi işletmenin kontrolünde olmayan, sifir ortalamaya sahip hata terimini ifade etmektedir ve Ui' den bağımsızdır. Bu yönteme göre her bir işletme için teknik etkinlik, gözlenen üretim değeri ile olması gereken üretim değerinin bir birine oranlanması ile bulunmaktadır. Teknik etkinliğin hesaplanmasında aşağıdaki Eşitlik 2 kullanılmıştır:

$$
T E_{i}=\frac{Y_{i}}{Y_{i}^{*}}
$$

Formülde;

TEi; i’nci işletmenin teknik etkinliğini, Yi; gözlenen üretim değerini ve $\mathrm{Y}_{-} \mathrm{i}^{\wedge *}$; ise, tahmin edilen ve olması gereken üretim değerini ifade etmektedir.

İşletmelerin teknik yetersizliğini etkileyen faktörler aşağıda belirtilen Eșitlik 3 yardımıyla tahmin edilmiştir:

$$
1-U_{-} \mathrm{i}=\mathrm{z}_{-} \mathrm{i} \delta
$$

$\mathrm{Bu}$ eşitlikte zi; işletme düzeyinde teknik etkinliği açıklayan bağımsız değişkenler vektörünü ve $\delta$ ise tahmin edilecek parametreleri göstermektedir.

SSM'de üretim fonksiyonu tahmin edilirken; bağımlı değişken olarak tohumluk miktarı $(\mathrm{kg} / \mathrm{da})$ ve bağımsız değişkenler olarak işgücü (saat/da), gübre $(\mathrm{kg} / \mathrm{da})$, tohum $(\mathrm{kg} / \mathrm{da})$ ve değişken masraflar $(\mathrm{TL} / \mathrm{da})$ kullanılmıştır. Değişken masraflar, işgücü, gübre ve tohum değiş̧ken masrafları dışında kalan diğer değiş̧ken masraflardir.

SSM'de Cobb-Douglas tipi üretim fonksiyonu kullanılmış ve parametreler en yüksek olabilirlik (maximum likelihood) yöntemi ile tahmin edilmiştir. Bu araştırmada, SSM'nin tahmininde Coelli (1992) tarafından geliştirilen "Frontier 4.1" paket programı kullanılmıştır.

Teknik etkinliği belirleyen faktörlerin tespitinde, işletmelerden anket yoluyla elde edilen verilerden elde edilen değişkenler kullanılmıştır. Teknik etkinliği açıklamak için modele 7 değiş̧en dâhil edilmiştir. Yetersiz eğitim ve aile büyüklüğ̈̈ teknik yetersizliğin sebepleri olabileceğinden, modele işletme sahibinin eğitim süresi (yıl) ve aile büyüklüğü (kişi) değişkenleri dâhil edilmiştir. İşletme yöneticisinin deneyiminin teknik etkinlik üzerindeki etkisini, yani genç veya yaşlı çiftçilerin diğerlerine oranla daha etkin çalışıp çalışmadığını test edebilmek için modelde işletme sahibinin yaşı (yıl) değişken olarak kullanılmıştır. Kredi kullanımı (TL/da) değişkeni modelde yer alan diğer bir değişkendir. Kayıt tutma ile teknik etkinlik skoru arasındaki ilişkiyi ölçebilmek için de kukla değişken $(0=$ kayıt tutmuyor; $1=$ kayıt tutuyor $)$ kullanılmıştır. Ayrıca buğday tohumluğu yetiştiriciliğinde yaygın olan kiracılık ve ortakçılığın teknik etkinlik üzerindeki etkisini ölçmek için; kiracılık ve ortakçılıkla işlenen 
arazi miktarı (da) değişkeni modele dâhil edilmiştir. Son olarak uzmanlaşmanın etkinlik üzerindeki etkisini ölçmek üzere buğday tohumluğu için ayrılan alan (da) modele dâhil edilmiştir.

\section{Bulgular ve Tartışma}

\subsection{Incelenen işletmelerde teknik etkinlik}

İnceleme alanında faaliyet gösteren işletmeler 5.12 saat işgücü, $46.04 \mathrm{~kg}$ gübre, $26.74 \mathrm{~kg}$ tohum ve dekara 104.16 TL değişken masraf kullanarak ortalama 0.56 ton/da buğday tohumluğu üretmektedirler (Çizelge 1). İncelenen işletmeler, işletme arazisi büyüklüğü, aktif sermaye, öz sermaye ve elde ettiği üretim değeri bakımından büyük ölçekli işletmelerdir. Ortalama işletme arazisi büyüklüğü yaklaşı 464 dekar civarındadır. $\mathrm{Bu}$ işletmeler işletme arazisi dekarı başına 4479.78 TL aktif sermaye kullanarak; 755.13 TL gayri safi üretim değeri (GSÜD), 239.41 TL brüt kar (BK) ve 172.23 TL tarımsal gelir elde etmektedirler. İşletme yöneticileri ortalama 44 yaşındadır. İşletme yöneticilerinin eğitim gördüğü süre ortalama 8 yıldır. İşletme arazisi dekarı başına kredi kullanımı 97.94 TL ve kiracılık ve/veya ortakçılıkla işlenen arazi miktarı ise yaklaşık 57 dekardır. İşletmeler ortalama 129 dekar arazide tohumluk buğday yetiştirmektedirler (Çizelge 1).

SSM'ne ait tahminler Çizelge 2'de verilmiştir. Modele ait varyans parametreleri istatistik açıdan önemlidir ve teknik etkinliğin tohumluk yetiştiriciliği miktarı üzerine etkisi olduğunu göstermektedir $(p<0,01)$. Bu durum en küçük kareler yöntemiyle tahmin edilen deterministik üretim fonksiyonunun verileri temsil etmede yeterli olmayacağını ifade etmektedir.

Çizelge 1. Stokastik sınır modelinde kullanılan değişkenler ve işletmelerin sosyo ekonomik özellikleri

\begin{tabular}{|c|c|c|c|c|c|}
\hline & Değişkenler/özellikler & Ortalama & $\begin{array}{l}\text { Standart } \\
\text { sapma }\end{array}$ & Minimum & Maksimum \\
\hline \multirow{5}{*}{ 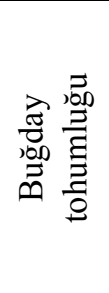 } & Verim $\left(\right.$ ton $\left.\mathrm{da}^{-1}\right)$ & 0.56 & 0.094 & 0.45 & 0.85 \\
\hline & İşgücü (saat da $\left.{ }^{-1}\right)$ & 5.12 & 1.67 & 2.00 & 8.50 \\
\hline & Gübre $\left(\mathrm{kg} \mathrm{da}^{-1}\right)$ & 46.04 & 4.27 & 40.00 & 50.00 \\
\hline & Tohum $\left(\mathrm{kg} \mathrm{da}^{-1}\right)$ & 26.74 & 2.40 & 25.00 & 30.00 \\
\hline & Değişken masraf ( $€ /$ dekar) & 104.16 & 50.06 & 27.00 & 245.60 \\
\hline \multicolumn{2}{|c|}{ İşletme arazisi büyüklüğü (da) } & 463.71 & 435.26 & 85.00 & 2400.00 \\
\hline \multicolumn{2}{|c|}{ Aktif sermaye (bin $€)$} & 2073.20 & 2283.77 & 557.89 & 14879.95 \\
\hline \multicolumn{2}{|c|}{ Öz sermaye (bin Ł) } & 1781.37 & 2243.11 & 411.30 & 14799.95 \\
\hline \multicolumn{2}{|c|}{ Aktif sermaye $\left(€ d a^{-1}\right)$} & 4479.78 & 787.19 & 3500.32 & 7280.03 \\
\hline \multicolumn{2}{|c|}{ Öz sermaye (も da ${ }^{-1}$ ) } & 3755.41 & 1067.15 & 1646.74 & 6213.37 \\
\hline \multicolumn{2}{|c|}{ Gayri safi üretim değeri $\left(€ d a^{-1}\right)$} & 755.13 & 177.30 & 505.45 & 1446.11 \\
\hline \multicolumn{2}{|c|}{ Gayri saf hasıla $\left(€ d a^{-1}\right)$} & 792.05 & 178.56 & 527.62 & 1468.31 \\
\hline \multicolumn{2}{|c|}{ Brüt kar $\left(€ d a^{-1}\right)$} & 239.41 & 123.63 & 58.52 & 840.50 \\
\hline \multicolumn{2}{|c|}{ Saf hasıla $\left(€ d a^{-1}\right)$} & 134.64 & 140.12 & -79.84 & 777.79 \\
\hline \multicolumn{2}{|c|}{ Tarımsal gelir $\left(€ \mathrm{da}^{-1}\right)$} & 172.23 & 127.52 & 11.63 & 779.65 \\
\hline \multicolumn{2}{|c|}{ Aile büyüklüğü (kişi) } & 5.11 & 1.46 & 2.00 & 9.00 \\
\hline \multicolumn{2}{|c|}{ İşletme sahibinin yaşı (yıl) } & 44.25 & 11.12 & 23.00 & 64.00 \\
\hline \multicolumn{2}{|c|}{ Kredi kullanımı (も da $\left.{ }^{-1}\right)$} & 97.94 & 126.57 & 0.00 & 650.00 \\
\hline \multicolumn{2}{|c|}{ İşletme sahibinin eğitim süresi (yıl) } & 8.01 & 2.71 & 5.00 & 13.00 \\
\hline \multicolumn{2}{|c|}{$\begin{array}{l}\text { Kiracılık veya ortakçılık ile işlenen arazi miktarı } \\
\text { (da) }\end{array}$} & 56.85 & 75.99 & 0.00 & 413.00 \\
\hline \multicolumn{2}{|c|}{ Buğday tohumluğu arazisi (da) } & 129.04 & 97.48 & 22.50 & 518.00 \\
\hline
\end{tabular}


Çizelge 2. Cobb-Douglass tipi stokastik sınır modeline ait parametre tahminleri

\begin{tabular}{lccc}
\hline \multicolumn{1}{c}{ Değişkenler } & Parametreler & Standart hata & t- değeri \\
\hline Sabit & Üretim fonksiyonu & & \\
İşü̈cü $\left(\mathrm{saat} \mathrm{da}^{-1}\right)$ & 1.08 & 0.17 & $6.38^{* * *}$ \\
Gübre $\left(\mathrm{kg} \mathrm{da}^{-1}\right)$ & -0.09 & 0.007 & $-13.13^{* * *}$ \\
Tohum $\left(\mathrm{kg} \mathrm{da}^{-1}\right)$ & -0.001 & 0.001 & $-9.27^{* * *}$ \\
Değişken masraf $\left(€ \mathrm{da}^{-1}\right)$ & 0.005 & 0.001 & $3.65^{* * *}$ \\
Elastikiyetler toplamı & 0.003 & 0.0002 & $14.37^{* * *}$ \\
\end{tabular}

Teknik yetersizliği açıklayan faktörler

\begin{tabular}{|c|c|c|c|}
\hline Sabit & 0.14 & 0.18 & 0.76 \\
\hline Aile büyüklüğg̈ (kişi) & 0.006 & 0.002 & $2.37 * *$ \\
\hline İşletme sahibinin yaşı (yıl) & 0.003 & 0.0003 & 0.89 \\
\hline Kredi kullanımı $\left(€ \mathrm{da}^{-1}\right)$ & 0.000004 & 0.00003 & 0.15 \\
\hline İşletme sahibinin eğitim süresi (yıl) & -0.003 & 0.001 & $-2.32 * *$ \\
\hline Kaylt tutma ( $1=$ tutuyor; $0=$ tutmuyor) & -0.02 & 0.009 & $-2.13 * *$ \\
\hline $\begin{array}{l}\text { Kiracılık veya ortakçılık ile işlenen arazi miktarı } \\
\text { (da) }\end{array}$ & 0.0001 & 0.00005 & $1.87 *$ \\
\hline Buğday tohumluğu için ayrılan arazi miktarı (da) & -0.0001 & 0.00004 & $-3.00 * * *$ \\
\hline \multicolumn{4}{|c|}{ Varyans parametreleri } \\
\hline Sigma & 0.0008 & 0.0001 & $6.23 * * *$ \\
\hline Gamma & 1.00 & 5.00 & 0.20 \\
\hline Loglikelihood & \multicolumn{2}{|c|}{$154.36(48.23)$} & \\
\hline
\end{tabular}

Olabilirlik oranı testi (likelihood-ratio test) sonuçları, teknik yetersizliğin etkisinin stokastik olduğunu ifade eden başlangıç hipotezinin reddedildiğini göstermiştir. Üretim fonksiyonunda yer alan iş gücü $(\mathrm{p}<0.01)$ ve gübre $(\mathrm{p}<0.01)$ değişkenlerine ait parametreler, buğday tohumluğu üretim miktarı ile bu değişkenler arasında negatif bir ilişki olduğunu göstermektedir. İş gücü ve gübre değiş̧kenleri için tahmin edilen elastikiyet katsayıları sirasıyla $\quad-0.09$ ve -0.001 'dir. Bu katsayılar birim alanda kullanılan iş gücünün ve gübrenin miktarının azaltılmasının, buğday tohumluğu üretimini artıracağına işaret etmektedir. Üretim fonksiyonunda yer alan değişken masraf ve tohum değişkenlerine ait katsayılar, buğday tohumluğu üretim miktarı ile bu değişkenler arasında pozitif bir ilişki olduğunu göstermektedir $(\mathrm{p}<0.01)$. Tohum $(p<0.01)$ ve değişken masraf $(p<0.01)$ değişkenleri için tahmin edilen elastikiyet katsayıları sirasiyla 0.005 ve 0.003 'tür. $\mathrm{Bu}$ katsayılar birim alanda kullanılan tohumun ve değişken masrafların miktarının arttırılmasının, buğday tohumluğu üretimini artıracağına işaret etmektedir. Elastikiyet katsayıları toplamı incelenen işletmelerde ölçeğe azalan getirinin söz konusu olduğuna işaret etmektedir (Çizelge 2).
Etkinlik analizi sonuçları inceleme alanında teknik etkinliğin 0.68 ile 0.96 arasında değişmekte olup, ortalama 0.81 olduğunu göstermiştir. İncelenen işletmeler teknik yetersizliklerini ortadan kaldırarak, üretim miktarında hiçbir azalma olmaksızın kullandıkları girdi miktarlarını \%19 oranında azaltabileceklerdir. İncelenen işletmelerin \%47'sinin teknik etkinlik katsayısı 0.76 ila 0.80 arasında, \% 22 'sinin teknik etkinlik katsayısı 0.81 ila 0.85 arasinda, $\%$ 10'unun teknik etkinlik katsayss 0.71 ila 0.75 arasında ve diğer \% 10'u ise, 0.86 ila 0.90 arasında teknik etkinlik katsayısına sahiptir (Şekil 2).

Kredi kullanımı ve işletme sahibinin yaşı değişkenleri hariç, teknik yetersizliği açıklamak için seçilen bütün değişkenler istatistik açıdan önemli bulunmuştur ve hepsinin işareti beklenen yöndedir. Eğitim görülen yıl sayısı, buğday tohumluğu için ayrılan arazi miktarı ve kayıt tutma teknik yetersizliği negatif yönde etkiliyorken; aile büyüklüğü ve kiracılık veya ortakçılık ile işlenen arazi miktarı değişkenleri ise teknik yetersizliği pozitif yönde etkilemektedir (Çizelge 2). 


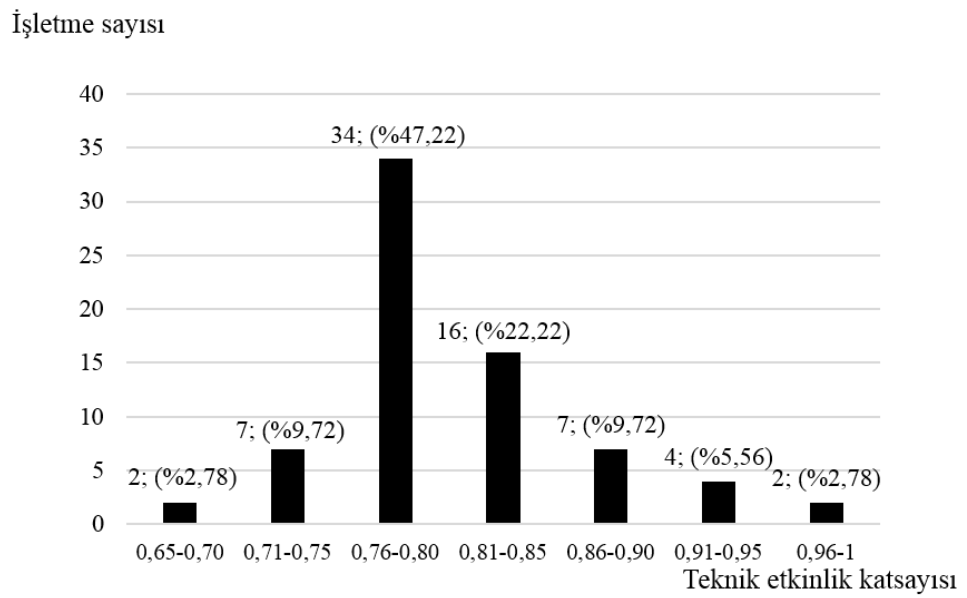

Şekil 2. İşletmelerin teknik etkinlik katsayılarının dağılımı

Çizelge 3. Etkin ve etkin olmayan işletmelerin verim, girdi kullanımı ve bazı sosyo-ekonomik özellikleri

\begin{tabular}{|c|c|c|c|c|c|}
\hline \multirow{2}{*}{\multicolumn{2}{|c|}{ Değişkenler/özellikler }} & \multicolumn{2}{|c|}{ Etkin işletmeler } & \multicolumn{2}{|c|}{ Etkin olmayan işletmeler } \\
\hline & & Ortalama & Standart hata & Ortalama & Standart hata \\
\hline \multirow{5}{*}{ 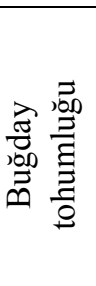 } & Verim $\left(\operatorname{ton} \mathrm{da}^{-1}\right)^{* * *}$ & 0.63 & 0.02 & 0.51 & 0.01 \\
\hline & İşgücü (saat da $\left.{ }^{-1}\right)$ & 4.83 & 0.31 & 5.31 & 0.25 \\
\hline & Gübre $\left(\mathrm{kg} \mathrm{da}^{-1}\right)^{* *}$ & 44.83 & 0.76 & 46.86 & 0.64 \\
\hline & Tohum $\left(\mathrm{kg} \mathrm{da}^{-1}\right)$ & 27.24 & 0.47 & 26.40 & 0.35 \\
\hline & Değişken masraf $\left(€\right.$ da $\left.^{-1}\right)$ & 104.85 & 7.13 & 103.69 & 8.70 \\
\hline \multicolumn{2}{|c|}{ Gayri safi üretim değeri $\left(€\right.$ da $\left.^{-1}\right)$} & 817.78 & 41.84 & 712.88 & 18.53 \\
\hline \multicolumn{2}{|c|}{ Gayri saf hasıla $\left(€ \mathrm{da}^{-1}\right)^{* *}$} & 856.15 & 41.48 & 748.82 & 19.22 \\
\hline \multicolumn{2}{|c|}{ Brüt kar $\left(€ d a^{-1}\right)^{* *}$} & 278.50 & 29.43 & 213.05 & 13.05 \\
\hline \multicolumn{2}{|c|}{ Saf hasıla $\left(€ \mathrm{da}^{-1}\right)^{* *}$} & 177.58 & 33.15 & 105.68 & 15.11 \\
\hline \multicolumn{2}{|c|}{ Tarımsal gelir $\left(€ \mathrm{da}^{-1}\right)^{*}$} & 211.05 & 30.82 & 146.05 & 13.10 \\
\hline \multicolumn{2}{|c|}{ Aktif sermaye $\left(€ \mathrm{da}^{-1}\right)^{* * *}$} & 4802.96 & 167.03 & 4261.82 & 94.92 \\
\hline \multicolumn{2}{|c|}{ Öz sermaye $\left(€ d a^{-1}\right) * * *$} & 4205.14 & 223.76 & 3452.11 & 129.69 \\
\hline \multicolumn{2}{|c|}{ Aile büyüklüğü (kişi)* } & 4.93 & 0.28 & 5.23 & 0.22 \\
\hline \multicolumn{2}{|c|}{ İşletme sahibinin yaşı (yıl) } & 44.90 & 2.04 & 43.81 & 1.73 \\
\hline \multicolumn{2}{|c|}{ Kredi kullanımı ( $\left.€ d a^{-1}\right)$} & 103.06 & 25.06 & 94.50 & 18.62 \\
\hline \multicolumn{2}{|c|}{ İşletme sahibinin eğitim süresi (y1l)*** } & 9.03 & 0.49 & 7.33 & 0.39 \\
\hline \multicolumn{2}{|c|}{$\begin{array}{l}\text { Kiracılık veya ortakçılık ile işlenen arazi } \\
\text { miktarı (da) }\end{array}$} & 51.36 & 13.24 & 60.55 & 12.14 \\
\hline \multicolumn{2}{|c|}{ Buğday tohumluğu için ayrılan arazi (da) } & 149.28 & 22.39 & 115.40 & 11.71 \\
\hline
\end{tabular}

*, **, *** sırasılla $\% 10, \% 5$ ve $\% 1$ önem düzeyinde istatistik açıdan anlamlı

Eğitim görülen yıl sayısı ve kayıt tutma teknik yetersizliği negatif yönde etkilemektedir $(\mathrm{p}<0.05)$. Eğitim görülen yıl sayısı arttıkça, işletmelerde teknik etkinlik artmaktadır. Kayıt tutma değişkeni için tahmin edilen katsayı, teknik açıdan kayıt tutanların, tutmayanlara göre daha etkin olduğunu göstermektedir 
$(\mathrm{p}<0.05)$. Aynı zamanda buğday tohumluğu için ayrılan arazi miktarı da teknik yetersizliği negatif yönde etkilemektedir. Tohumluk için ayrılan arazi miktarı arttıkça, yani uzmanlaşma arttıkça teknik etkinlik artacaktır (Çizelge 2).

SSM modelinde tespit edilen teknik etkinlik ile aile büyüklügü̈ $(p<0.05)$ ve kiracılık ve/veya ortakçılık ile işlenen arazi miktarı $(\mathrm{p}<0.10)$ arasındaki pozitif ilişki, aile büyüklüğü arttıkça veya kiracılık-ortakçılık ile işlenen arazi miktarı arttıkça teknik etkinliğin azaldığını göstermektedir (Çizelge 2).

Karşılaştırmalı etkinlik analizi sonuçları, teknik olarak etkin olan işletmelerin diğerlerine oranla faaliyetlerini dekar başına daha yüksek aktif ve öz sermaye ile sürdürdüğünü göstermiştir $(p<0.01)$. Karşılaştırmalı etkinlik analizi sonuçları, teknik olarak etkin olan işletmelerin diğerlerine oranla daha az nüfusa sahip olduklarını göstermiştir $(p<0.10)$. Diğer taraftan teknik olarak etkin olan işletmelerde işletme yöneticisi profili, etkin olmayanlardan daha iyidir. Etkin işletmelerde işletme yöneticileri daha eğitimlidir $(\mathrm{p}<0.01)$. Etkin işletmelerde dekar başına elde edilen GSÜD $(p<0.05)$, GSH $(p<0.05)$, BK $(p<0.10)$, SH $(p<0.05)$ ve TG $(p<0.05)$, etkin olmayanlardan daha fazladır. Etkin işletmelerin dekara buğday tohumluğu verimleri, etkin olmayanların verimlerine göre daha yüksektir $(\mathrm{p}<0.01)$. Etkin işletmelerin dekara gübre kullanımları, etkin olmayanların dekara gübre kullanımlarına göre daha düşüktür $(\mathrm{p}<0.05)$ (Çizelge 3$)$.

\section{Sonuç ve Öneriler}

Türkiye'de TR83 Bölgesinde yer alan üç farklı ilde (Amasya, Çorum, Tokat) faaliyet gösteren ve buğday tohumluğu yetiştiren işletmelerin incelendiğ $\mathrm{i}$ bu araştırmada, incelenen işletmelerin Türkiye'deki tipik tarımsal işletmelerden farklı olarak daha büyük işletme arazisine sahip, yeniliklere açı, alet makine parkı yeterli, sermayeye yapıları güçlü ve pazarla daha fazla bütünleşmiş işletmeler olduğu saptanmıştır. İnceleme alanında buğday tohumluğu yetiştiren tarım işletmeleri daha çok tarla bitkileri üretimi konusunda uzmanlaşmış işletmelerdir.

İnceleme alanında teknik etkinlik iyi düzeyde olsa da, teknik olarak etkin olmayan işletmelerin üretimde hiçbir azalma olmaksızın girdilerini buğday tohumluğu yetiştiriciliğinde $\% 19$ oranında azaltabilmesi mümkündür. İncelenen işletmelerde teknik etkinliğin yüksek çıkmasının sebebi işletmelerin optimum ölçeğe yakın bir düzeyde çalışmalarıdır. Aynı zamanda bu katsayılar göstermektedir ki, işletmeler sahip oldukları üretim faktörlerini optimum düzeye yakın dağıtmaktadırlar. Tarla ürünlerinde uzmanlaşmış, sulu, verimli arazilere sahip olan ve yetiştirilecek olan tohumluk türüne göre 2 veya 4 yıllık münavebe için uygulanan münavebe sisteminde gerekli olan arazi büyüklüğüne fazlasıyla sahip olan işletmeler, tohum üretici firmalar tarafindan özellikle seçilip yetiştiricilik için sözleşme yapılmaktadır. İşletme sahipleri ise, genellikle yenilikleri benimseme konusunda istekli, yörede sözü geçen, eğitim seviyeleri yüksek ve lider olarak tanımlanabilecek çiftçilerden oluşmaktadır. Bu işletmeler, sözleşme yapan tohumluk üreticisi işletmeler tarafindan; olası bir zararlı, hastalık, iklim riski ve/veya yetiştiricilik riski gibi sorunlar oluştuğunda, bu sorunların üstesinden gelebilecek, yeterli alet-makina parkına, belirli bir ekonomik büyüklüğe, bitkisel üretim uzmanlığına ve tohumluk üreticisi işletmelerle uyumlu çalışma isteğine sahip işletmeler arasından özenle seçilen işletmelerdir. Bu yüzden beklenildiği gibi teknik etkinlik skorları çok yüksektir.

İnceleme alanında buğday tohumluğu yetiştiriciliğinde tohum, gübre ve işgücü dışında kalan diğer değişken masrafların gereğinden fazla olduğu ve bunun teknik etkinliği düşürdüğü saptanmıştır. İncelenen işletmelerde kullanılan tohum miktarını ve diğer değişken masrafların hemen hemen tamamını tohumluk yetiştiren işletmeyle sözleşme yapan tohum üretici firmalar belirlediğinden, tohum yetiştiren firmaların tohumluk yetiştiriciliğiyle ilgili teknik uygulamaları gözden geçirmesi ve daha doğru olan uygulamaların işletmeler tarafından uygulanmasını sağlamaları buğday tohumluğu yetiştiriciliğinde teknik etkinliği artırabilecektir.

Karşılaştırmalı analiz sonuçları teknik olarak etkin çalışan işletmelerin, diğerlerine göre daha başarılı olduğunu ortaya koymuştur. İnceleme alanında bulunan ve eğitim seviyesi düşük olan çiftçilerin özel eğitim programlarına tabi tutularak eğitim seviyesindeki yetersizliğin etkilerini azaltılmalıdır. Çiftçi eğitim ve yayım programlarının düzenlenmesinde hedef kitlenin iyi tanınması ve ihtiyaç analizinin iyi yapılması eğitim ve yayım çalışmalarının etkinliğini artırabilecektir. Söz konusu eğitim çalışmalarında optimum girdi kullanımına ağırlık verilmesi ve girdilerin fiyatlarıyla bağlantılı olarak kullanımına yoğunlaşılması inceleme alanında teknik etkinliği artırabilecektir.

\section{Teşekkür}

$\mathrm{Bu}$ çalışma doktora tezinden derlenmiş olup, Ondokuz Mayıs Üniversitesi PYO.ZRT.1904.13.021 nolu proje ile BAP tarafindan desteklenmiştir. Ondokuz Mayıs Üniversitesi Proje Yönetim Ofisine teşekkür ederiz.

\section{Kaynaklar}

Acar Ş., 2008. Avrupa Birliği ve Türkiye'de tohumculuk sektörünün yapılanması, T.C. Tarım ve Köyişleri Bakanlığı, Dış İlişkiler ve Avrupa Birliği Koordinasyon Dairesi Başkanlığı, AB Uzmanlık Tezi, Ankara

Akdoğan İ., 2005. Ankara ili tarım işletmelerinde sslah edilmiş buğday çeşitlerinin sertifikalı tohumluklarının kullanım düzeyleri ve işletme ekonomisine katkılarının değerlendirilmesi, Yüksek Lisans Tezi, Ankara Üniversitesi, Fen Bilimleri Enstitüsü, Ankara.

Arısoy H., 2005. Tarımsal araştırma enstitüleri tarafindan yeni geliştirilen buğday çeşitlerinin tarım işletmelerinde 
kullanım düzeyi ve geleneksel çeşitler ile karşılaştırmalı ekonomik analizi-Konya ili örneği, Doktora Tezi, Ankara Üniversitesi, Fen Bilimleri Enstitüsü, Ankara.

Balcı E. Ö., 1993. Türkiye'de bitkisel tohumculuğun genel ve tarım işletmeleri düzeyindeki sorunları üzerine bir araştırma, Yüksek Lisans Tezi, Çukurova Üniversitesi, Fen Bilimleri Enstitüsü, Adana.

Battese G. E., Coelli T. J., 1995. A model for technicalin efficiency effects in a stochastic frontier production function for panel data, Empirical Economics, 20: 325332.

Coelli T. J., 1992. A computer program for frontier production function estimation: frontier, Version 2.0, Economics Letters, 39:29-32.

Coelli T. J., Rao D. S. P, Battese G. E., 1998. An introduction to efficiency and productivity analysis: Boston, USA, Kluwer Academic Publishers.

Demirtaş B., Keleş D., 2005. Çukurova bölgesinde sebze tohumculuğunun pazarlama yapıs1, Türkiye 2 . Tohumculuk Kongresi, Adana, 9-11 Kasım.

Ike P. C., 2008. Estimating production technical efficiency of Irvingia seed (ogbono) species farmers in Nsukka Agricultural zone of Enugu State, Nigeria, J. Sustainable Agric. Res., 28:1-7.

Khanal N. P., Maharjan K. L., Sapkota A., 2012. Technical efficiency in wheat seed production: a case study from Tarai region of Nepal, Hiroshima University, Journal of International Development and Cooperation, 19(1):4150.

Srinivas T., Rizvi S. J. H., Aw-Hassan A., Manan A. R., Kadian M. S., 2012. Technical efficiency of seed potato farmers of Badakshan province of Afghanistan, Potato Journal, 39(2), 118-127.

URL-1:http://www.tuik.gov.tr/PreIstatistikTablo.do?istab_id $=1590$, (Ziyaret tarihi: 10 Şubat 2017).

URL-2:http://www.oka.org.tr/Documents/temel\%20G\%C3\% B6stergelerle\%20 TR 83. pdfhtml, (Ziyaret tarihi: 10 Ocak 2015).

URL-3:http://biruni.tuik.gov.tr/bitkiselapp/bitkisel.zul, (Ziyaret tarihi: 10 Şubat 2017).

Usal G., 1996. Adana ilinde bitkisel tohum üretimi yapan firmaların üretim dağıtım yapısı, sorunları ve çözüm önerileri, Yüksek Lisans Tezi, Çukurova Üniversitesi, Ziraat Fakültesi, Fen Bilimleri Enstitüsü, Adana.

Yağdı K., Yılmaz K., Sezer N., Aydemir T., Bağc1 S. A., 2010. Türkiye'de tarla bitkileri tohumluk üretimi ve kullanımı ile tohumculuk sisteminin genel değerlendirilmesi, Ziraat Mühendisliği VII. Teknik Kongresi, Bildiriler Kitabı 2. Cilt, Ankara, 861-875. 